\title{
Aplicabilidade de Protocolos de Avaliação Rápida (PARs) no diagnóstico ambiental de sistemas fluviais: o caso do Parque Nacional da Serra do Gandarela (MG)
}

\section{Applicability of Rapid Assessment Protocols to the environmental diagnosis of river systems: the case of the Serra do Gandarela National Park (MG)}

\author{
Nayara Mariana Gonzaga Rosa \\ Mestranda em Geografia e Análise Ambiental, \\ Universidade Federal de Minas Gerais, Brasil \\ nayara.mariana07@gmail.com \\ Antônio Pereira Magalhães Junior \\ Professor titular do Departamento de Geografia, \\ Universidade Federal de Minas Gerais, Brasil \\ antonio.magalhaes.ufmg@gmail.com
}

\begin{abstract}
Resumo
Os processos decisórios de gestão de bacias hidrográficas dependem de informações qualificadas, pautadas na realidade e diversidade dos sistemas hídricos. No Brasil, o diagnóstico ambiental de sistemas fluviais baseia-se principalmente em análises realizadas através de estações de monitoramento. Estas avaliações, no entanto, apresentam alto custo e consideram apenas parâmetros físico-químicos e bacteriológicos da água, desconsiderando aspectos morfológicos, sedimentológicos e ecológicos. Frente a esta limitação, torna-se desejável a utilização de ferramentas práticas, que permitam uma análise ambiental pouco onerosa e integrada de cursos d'água. Diante deste contexto, o presente estudo teve como objetivo conceber um Protocolo de Avaliação Rápida (PAR) para aplicação em sistemas fluviais do Parque Nacional da Serra do Gandarela (MG) e discutir suas potencialidades como instrumento de suporte ao monitoramento e gestão de recursos hídricos. Os resultados demonstraram que o PAR pode ser considerado como uma ferramenta viável, já que a partir de sua aplicação foi possível detectar, de forma rápida e prática, alterações gradativas na qualidade ambiental do curso d'água avaliado.
\end{abstract}

Palavras-chave: Protocolos de Avaliação Rápida, Gestão de sistemas fluviais, Avaliação ambiental, Qualidade ambiental.

\begin{abstract}
Decision-making processes for river basin management depend on qualified information, based on the reality and diversity of water systems. In Brazil, the environmental diagnosis of river systems is based mainly on the analysis carried out through monitoring stations. These assessments, however, present high costs and consider only physical-chemic and bacteriological water parameters, disregarding morphological, sedimentological and ecological aspects. Faced with this limitation, it is desirable to use practical tools that allow a cheap and integrated evaluation of river systems. In this context, the present study aimed to design a Rapid Assessment Protocol for application in river systems of the Serra do Gandarela National Park (MG) and to discuss its potential as an instrument to support the monitoring and management of water resources. The results showed that the protocol could be considered a viable tool, since from its application it was possible to detect, quickly and practically, gradual changes in the environmental quality of the evaluated watercourse.
\end{abstract}

Keywords: Rapid Assessment Protocols, Fluvial systems management; Environmental Assessment; Environmental quality. 


\section{INTRODUÇÃO}

Os sistemas fluviais são fundamentais para a manutenção de variados processos ambientais e socioeconômicos, dentre os quais se destacam o ciclo hidrológico, o transporte de sedimentos, a regulação de ecossistemas, o abastecimento público e as atividades agrícolas e industriais. Como mananciais de recursos hídricos, estes são alvo dos mais variados tipos de intervenções antrópicas, estando sujeitos a fatores que podem comprometer seu comportamento hidromorfológico e a qualidade ambiental. Além das alterações diretas, os cursos d'água também espelham a realidade de suas bacias hidrográficas, refletindo estados de preservação ou degradação e transmitindo efeitos negativos de montante à jusante.

Para fundamentar ações de gestão de recursos e sistemas hídricos torna-se cada vez mais clara a necessidade de se obter informações qualificadas, pautadas na realidade e diversidade das regiões hidrográficas (LEMOS et al., 2014). Assim, a qualidade ambiental dos sistemas fluviais é considerada um importante objeto de avaliação para órgãos gestores e para as ciências ambientais.

No Brasil, o diagnóstico da qualidade ambiental de cursos d'água se dá principalmente por meio de estações de monitoramento, que fornecem dados para análises quantitativas direcionadas para a determinação de parâmetros físico-químicos e bacteriológicos da água. Apesar de gerarem uma quantidade de dados significativa, estas análises são onerosas, tendo em vista que envolvem a manutenção de equipamentos e contratação de profissionais especializados (RODRIGUES e CASTRO, 2008). Este aspecto se reflete, por sua vez, em lacunas de informações sobre o estado ambiental de sistemas fluviais, uma vez que o número de estações de monitoramento em operação varia entre localidades, devido principalmente à limitação de recursos financeiros.

Outro aspecto a se destacar é que estas análises quantitativas, apesar de importantes para o estabelecimento de indicadores de potabilidade ou qualidade da água, são insuficientes por si só para retratar a realidade ambiental de um sistema fluvial. Os cursos d'água são integrados por componentes e processos mais amplos do que a dimensão hídrica, englobando aspectos geomórficos, sedimentológicos e ecológicos. Assim, uma análise que se aproxime da realidade deste sistema só é possível a partir de uma perspectiva integrada, que considere todos os componentes e processos envolvidos (RODRIGUES, 2008).

No contexto de tais limitações, há a necessidade de se promover iniciativas voltadas para o monitoramento de sistemas fluviais a partir da utilização de ferramentas práticas, eficientes e com baixos custos de aplicação. Neste sentido têm-se os Protocolos de Avaliação Rápida (PARs), que são instrumentos desenvolvidos para auxiliar a caracterização e diagnóstico ambiental de cursos d'água a partir do levantamento e avaliação de parâmetros ambientais macroscópicos (PAFKLIN et al., 1989; HANNAFORD, et al., 1997; BARBOUR et al., 1999; CALLISTO et al., 2002; RODRIGUES, 2008; 
RODRIGUES e CASTRO, 2008; BIZZO et al,. 2014). Os PARs São ferramentas de fácil entendimento e aplicação, que permitem uma análise eficaz, prática e pouco onerosa. Além disso, agregam indicadores ambientais que vão além da qualidade da água, contribuindo para uma análise integrada. Sua utilização apresenta, portanto, potencial de avanços ao monitoramento da qualidade ambiental de sistemas fluviais.

Este trabalho visa conceber e apresentar um Protocolo de Avaliação Rápida para diagnóstico da qualidade ambiental de sistemas fluviais do Parque Nacional da Serra do Gandarela (MG), uma das mais recentes unidades de conservação do estado e cercada por pressões antrópicas. Neste caso, o PAR pode ilustrar e sinalizar a eficiência do Parque na proteção dos sistemas fluviais locais, dado que é uma unidade de conservação de proteção integral. Em termos específicos, pretende-se discutir as potencialidades dos PARs como instrumentos de suporte ao monitoramento da qualidade ambiental de cursos d'água e contribuir para os processos de gestão e proteção dos sistemas hídricos da Serra do Gandarela.

Com relação ao estudo de caso, foram selecionados segmentos do Riberão da Prata, o qual nasce no Parque Nacional e se estende até o município de Raposos (MG). Trata-se de um curso d'água enquadrado como classe 1 de acordo com a resolução CONAMA 357 de 17 Março de 2005, exercendo importantes funções ecológicas na unidade de conservação e apresentando importante potencial de lazer e turismo (LEITE et al., 2015).

\section{APLICAÇÃO DE PARs NA AVALIAÇÃO DA QUALIDADE AMBIENTAL DE SISTEMAS FLUVIAIS}

Até a década de 1970 o monitoramento ambiental nos Estados Unidos baseava-se sobretudo na realização de análises quantitativas. Em 1986, a EPA - Environment Protection Agency (a agência ambiental dos Estados Unidos), associada a agências de monitoramento de águas superficiais, deu início a estudos sobre qualidade das águas que resultaram em um relatório que enfatizava a reestruturação dos programas de monitoramento praticados, recomendava o desenvolvimento e a aplicação de técnicas de monitoramento biológico e sugeria a elaboração de um guia de avaliação do meio físico que associasse baixos custos e efetividade na identificação dos problemas existentes (RODRIGUES, 2008). Neste contexto, surgiram iniciativas para elaboração de Protocolos de Avaliação Rápida.

Os PARs são ferramentas desenvolvidas com o objetivo de auxiliar na caracterização e monitoramento ambiental de sistemas fluviais, a partir do levantamento e avaliação de informações qualitativas do meio. Baseia-se, assim, na observação in situ de uma série de parâmetros físicos e biológicos pré-definidos para, em seguida, estabelecer uma pontuação para o estado em que o ambiente se encontra. As pontuações atribuídas a cada um dos parâmetros avaliados indicam o estado 
de qualidade do sistema, em que notas maiores refletem um bom estado de conservação, enquanto notas menores indicam estados de degradação (PAFKLIN et al., 1989; HANNAFORD, et al., 1997; BABOUR et al., 1999; CALLISTO et al., 2002; RODRIGUES, 2008; RODRIGUES e CASTRO, 2008; BIZZO et al,. 2014)

É necessário destacar que os PARs não se propõem a ser documentos rígidos e conclusivos. Estes estão sujeitos a complementações e adequações de acordo com as especificidades regionais e locais, uma vez que as características dos corpos d'água variam em função de fatores como clima, relevo, geologia e uso e ocupação do solo. Realizadas as adaptações necessárias, os protocolos tornam-se aplicáveis a qualquer tipo de sistema fluvial (BARBOUR et al., 1999).

Um dos principais aspectos positivos relacionados ao uso dos PARs é a facilidade e rapidez de sua aplicação. Em um estudo desenvolvido em trechos fluviais no Parque Nacional da Serra do Cipó - MG e no Parque Nacional da Bocaina - RJ, Callisto et al. (2002) verificaram a facilidade da aplicação de um PAR adaptado para a avaliação da diversidade de habitats. Os autores constataram que, além de não haver diferença significativa entre o padrão de respostas obtidas de 50 estudantes treinados e 50 não treinados, o tempo gasto na aplicação do protocolo em cada trecho de rio analisado foi de apenas de 20 a 30 minutos.

Diante deste aspecto, entende-se que em geral não é necessária a atuação de especialistas para a utilização do instrumento, que pode ser estendido a pessoas de qualquer segmento social bastando um treinamento prévio (RODRIGUES e CASTRO, 2008). Este fator abre precedentes para a aplicação do protocolo pela população em geral e um consequente aumento da participação popular no monitoramento de recursos hídricos.

Buss et al. (2003) acreditam que um aspecto essencial de um programa de avaliação de recursos hídricos é a habilidade do mesmo em traduzir a informação tanto para tomadores de decisão, quanto para o público em geral. Para os autores, na maioria das vezes a complexidade dos resultados dos métodos tradicionais impede a interpretação pelo público leigo, tornando a informação restrita. Os protocolos, por outro lado, são ferramentas qualitativas que permitem uma maior compreensão das informações obtidas, tornando-as mais acessíveis.

O fato de o método contribuir com a redução de custos na avaliação ambiental é outro aspecto positivo, uma vez que, estabelecido o protocolo, a aplicação não é onerosa, o que permite que uma vasta malha de pontos de amostragem seja estabelecida. Deve-se destacar também que a ferramenta possibilita uma sensibilização frente a questões referentes à preservação de recursos hídricos, podendo ser útil até mesmo como um alerta para acidentes ambientais (BIZZO et al., 2014).

Apesar da gama de aspectos positivos, o monitoramento via protocolos apresenta, assim como qualquer técnica qualitativa, um significativo grau de subjetividade. Ao contrário das avaliações de caráter quantitativo, nos quais os valores dos parâmetros físico-químicos são obtidos 
através de aparelhos, as pontuações atribuídas via PAR baseiam-se apenas na observação do meio, dependendo, assim, dos conhecimentos do avaliador e de sua capacidade de perceber as características locais. Esta subjetividade, no entanto, pode ser amenizada com treinamento adequado do aplicador ou acompanhamento parcial e de suporte de avaliadores mais experientes (RODRIGUES, 2008).

Outro aspecto que merece destaque é que a maioria dos PARs aplicados no Brasil é voltada especificamente para a avaliação de características ecológicas de rios, buscando, através da observação de fatores físicos, avaliar a qualidade dos habitats e dos ecossistemas, o que de certa forma limita sua aplicação para outros fins. Como exemplo, têm-se os trabalhos de Callisto et al. (2002), Rodrigues (2008) e Minatti-Ferreira e Beaumord (2006). No entanto, apesar desta tendência geral, algumas pesquisas já abordaram o uso dos PARs para análises focadas em outros objetivos. É o caso dos trabalhos de Monteiro (2014), que elaborou um PAR voltado para a avaliação da estabilidade e suscetibilidade à erosão de taludes fluviais; Lemos et al. (2014), que aplicaram protocolos para análise de sistemas fluviais em áreas urbanas; e Lopes e Oliveira (2017), que desenvolveram um PAR para avaliação da qualidade sanitária e ambiental de balneários.

\section{A SERRA DO GANDARELA}

A Serra do Gandarela situa-se na porção NE da região do Quadrilátero Ferrífero, Minas Gerais. Abrange partes dos municípios de Caeté, Itabirito, Raposos, Ouro Preto, Mariana, Nova Lima, Rio Acima e Santa Bárbara e, apesar de estar a cerca de somente $65 \mathrm{Km}$ da Região Metropolitana de Belo Horizonte (RMBH), se configura como uma das áreas mais bem preservadas do contexto em que se insere.

Devido principalmente à diversidade paisagística, rica biodiversidade e grande potencial hídrico, a área foi identificada como prioritária para a conservação em Minas Gerais (LAMOUNIER et al., 2011), fato que culminou na criação do Parque Nacional da Serra do Gandarela em 2014 (Decreto s/n, de 13 de Outubro de 2014) (Figura 1). Segundo o ICMBio (2010), no parque foi indicada a existência de mais de mil nascentes e de cursos fluviais enquadrados nas classes Especial e 1, conforme a resolução CONAMA no 357 de 17 de Março de 2005.

Apesar do alto grau de preservação, a Serra insere-se no contexto do Quadrilátero Ferrífero, que sofre historicamente com intensas intervenções antrópicas ligadas principalmente à atividade minerária. Este fato, por sua vez, torna a área propensa a pressões e conflitos de uso da terra e da água. 


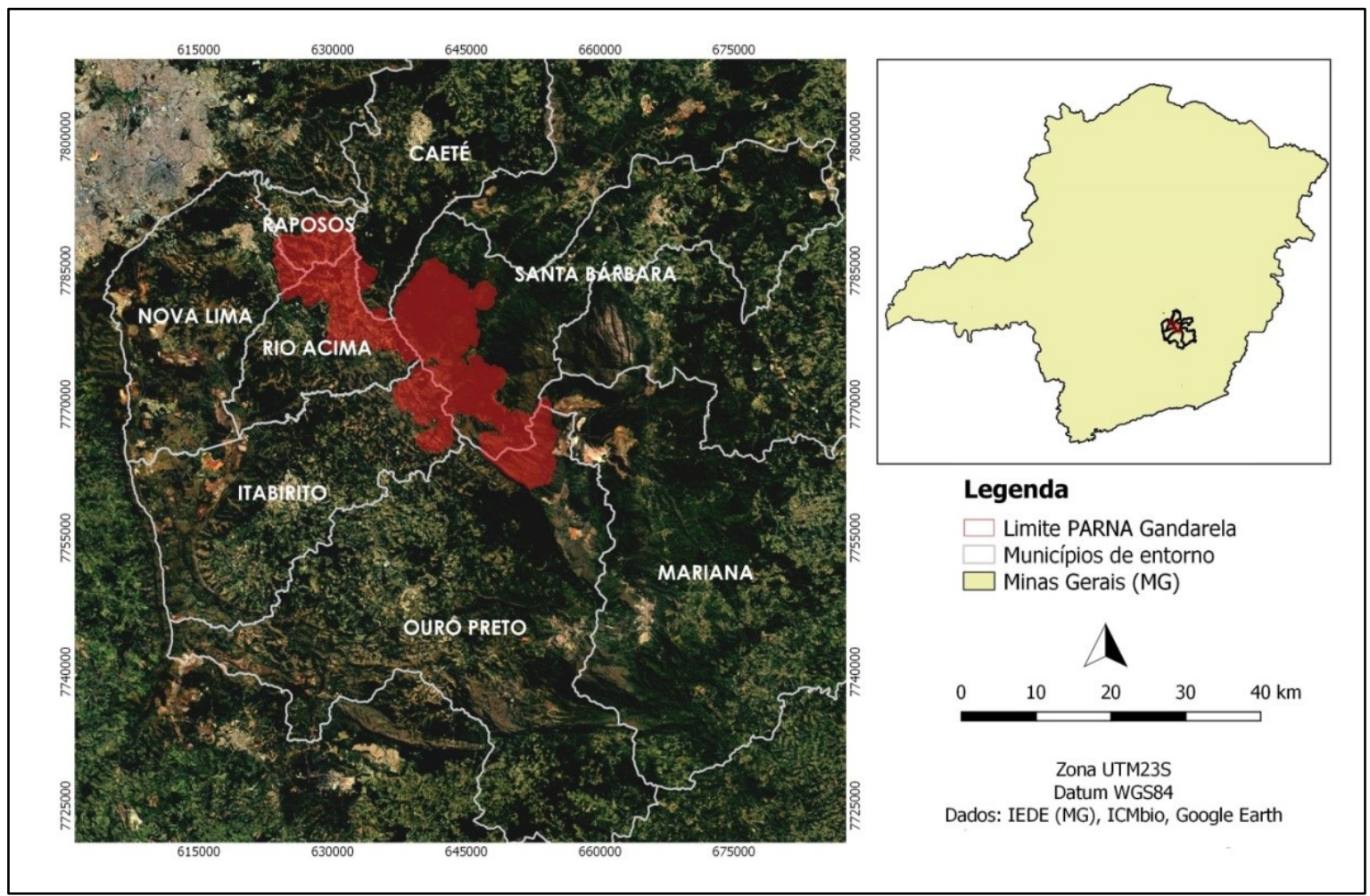

Figura 1 - Localização do Parque Nacional da Serra do Gandarela (MG).

Com nascentes no interior do PARNA Gandarela, a bacia hidrográfica do Ribeirão da Prata apresenta uma área de aproximadamente $100 \mathrm{~km}^{2}$ e deságua no Rio das Velhas na altura do município de Raposos, a aproximadamente $30 \mathrm{Km}$ de Belo Horizonte (Figura 2).

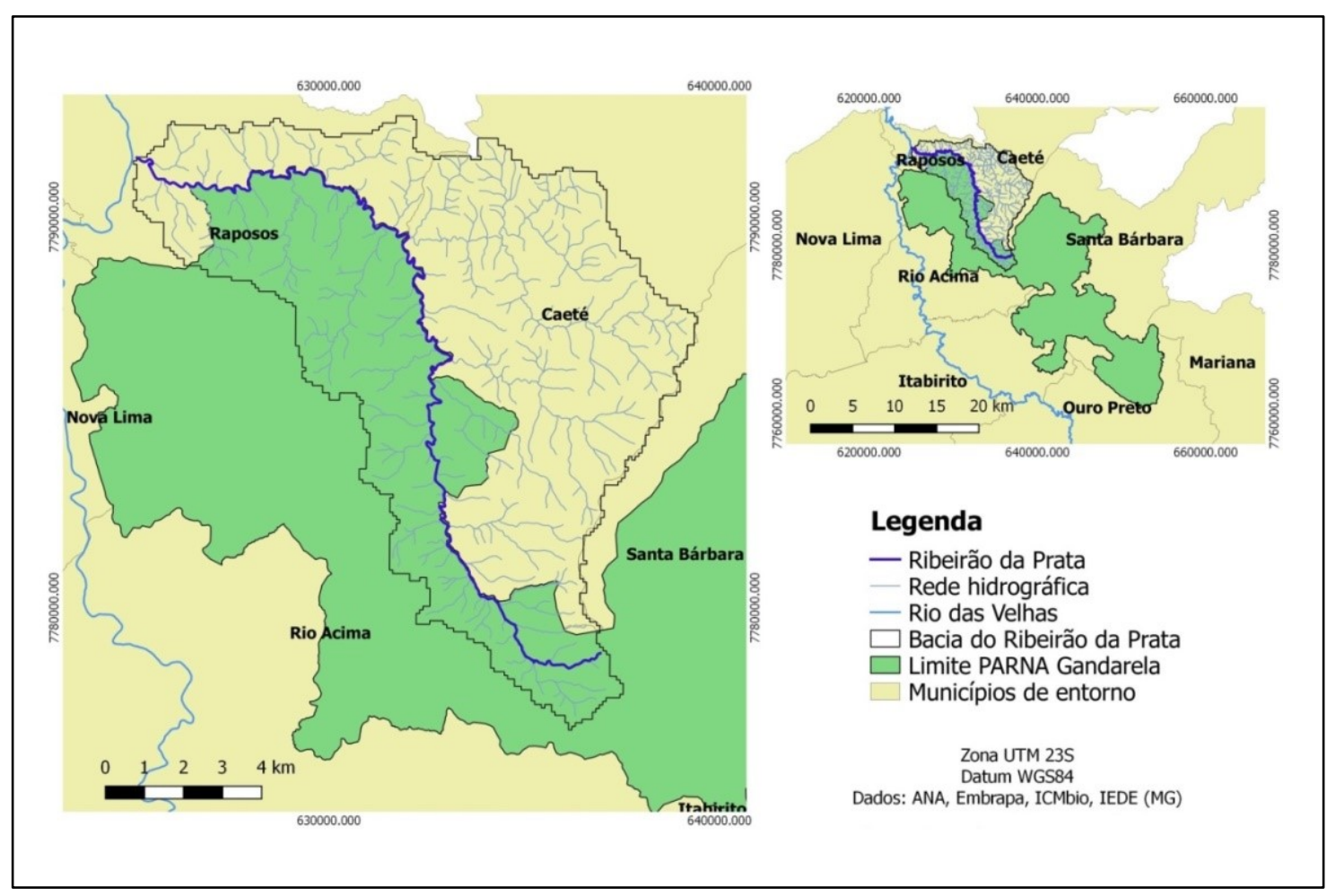

Figura 2 - Bacia hidrográfica do Ribeirão da Prata. 
O Ribeirão da Prata configura-se como um dos principais cursos d'água da região. Enquadrado na classe 1 conforme resolução CONAMA n 357 de 17 de março de 2005, exerce papel no equilíbrio ecossistêmico da unidade de conservação e configura-se como o principal bem natural com potencial de lazer e turismo em Raposos, sendo muito utilizado para fins recreacionais de contato primário (LEITE et al., 2015).

No que se refere aos tipos de vegetação, a bacia do Ribeirão da Prata conta com presença significativa de espécies arbóreas nas áreas de cabeceiras de drenagem e em fundos de vale (matas ciliares). Apresenta também expressiva vegetação de porte herbáceo-arbustivo, principalmente em áreas de cabeceiras e em interflúvios localizados na porção leste da bacia, onde as cotas altimétricas são mais elevadas (RAPOSO et al., 2010). Com relação aos usos antrópicos, estes ocorrem principalmente na porção norte da bacia, com áreas ocupadas por uso agropastoril; e na porção noroeste, ocupada pela mancha urbana de Raposos.

\section{PROCEDIMENTOS METODOLÓGICOS}

\subsection{Levantamento bibliográfico e seleção de indicadores}

A etapa inicial baseou-se em revisão acerca dos diferentes Protocolos de Avaliação Rápida apresentados na literatura. Através desta busca foi selecionado um modelo de PAR que deu bases para a elaboração da proposta apresentada no presente trabalho. O protocolo modelo selecionado foi o Quadro I apresentado por Callisto et al. (2002), em estudo intitulado “Aplicação de um protocolo de avaliação rápida da diversidade de habitats em atividades de ensino e pesquisa (MG - RJ)" (Tabela 1). Este protocolo avalia um conjunto de parâmetros fisicos do meio através de uma pontuação entre 0 e 4, que é atribuída a cada indicador com base na observação das condições ambientais locais. Ao final da avaliação as notas de todos os parâmetros são totalizadas, gerando os diagnósticos de qualidade ambiental dos segmentos fluviais, que variam entre "impactados", "alterados" e "naturais".

Os indicadores e o sistema de pontuação apresentados pelo modelo foram utilizados como referência para a elaboração do PAR aqui proposto.

Do protocolo de Callisto et al. (2002) foram incluídos os indicadores (1) tipo de ocupação das margens do corpo d'água; (2) avaliação de focos de erosão próxima e/ou nas margens do rio; (3) alterações antrópicas; (5) odor da água; (6) oleosidade da água; (7) transparência da água.

Optou-se por não avaliar os parâmetros (4) cobertura vegetal do leito, (8) odor dos sedimentos; (9) oleosidade do leito e (10) tipo de fundo. Os parâmetros 4 e 10 estão voltados à análise da diversidade de habitats, que não é o foco do presente estudo. Os parâmetros 8 e 9, por sua vez, são de difícil identificação em campo, tendo em vista que em muitos casos não é possível visualizar o leito dos cursos d'água. Também não foram avaliados indícios de assoreamento (incluído no 
parâmetro 2), uma vez que, apesar de se tratar de um indicador relevante, este só pode ser detectado com clareza a partir de estudos que avaliem a evolução temporal do sistema fluvial.

Tabela 1 - Quadro I utilizado por Callisto et al., 2002.

\begin{tabular}{|c|c|c|c|}
\hline \multicolumn{4}{|l|}{ Localização: } \\
\hline Data da coleta: $\ldots 1$ & \multicolumn{3}{|l|}{ Hora da coleta: } \\
\hline \multicolumn{4}{|l|}{ Tempo (situação do dia): } \\
\hline \multicolumn{4}{|l|}{ Modo de coleta (coletor): } \\
\hline Tipo de ambiente: ( ) Córrego & \multicolumn{3}{|l|}{ ) Rio } \\
\hline \multicolumn{4}{|l|}{ Largura: } \\
\hline \multicolumn{4}{|l|}{ Profundidade: } \\
\hline \multicolumn{4}{|l|}{ Temperatura da água: } \\
\hline \multirow{2}{*}{ Parâmetros } & \multicolumn{3}{|c|}{ Pontuaçăo } \\
\hline & 4 pontos & 2 pontos & 0 pontos \\
\hline $\begin{array}{l}\text { 1. Tipo de ocupação das } \\
\text { margens do corpo dágua } \\
\text { (principal atividade) }\end{array}$ & Vegetação natural & $\begin{array}{c}\text { Campo de } \\
\text { pastagem/Agricultura/M } \\
\text { onocultura/Reflorestame } \\
\text { nto }\end{array}$ & Residencial/Comercial//ndustrial \\
\hline $\begin{array}{l}\text { 2. Erosão próxima e/ou nas } \\
\text { margens do rio e assoreamento } \\
\text { em seu leito }\end{array}$ & Ausente & Moderada & Acentuada \\
\hline 3. Alterações antrópicas & Ausente & $\begin{array}{c}\text { Alterações de origem } \\
\text { doméstica (esgoto/lixo) }\end{array}$ & $\begin{array}{c}\text { Alterações de origem } \\
\text { industrial/urbana (fábricas, } \\
\text { siderurgias, canalização, retilização } \\
\text { do curso do rio) }\end{array}$ \\
\hline 4. Cobertura vegetal no leito & Parcial & Total & Ausente \\
\hline 5. Odor da água & Nenhum & Esgoto (ovo podre) & Óleo/industrial \\
\hline 6. Oleosidade da água & Ausente & Moderada & Abundante \\
\hline 7. Transparência da água & Transparente & Turva/cor de chá forte & Opaca ou colorida \\
\hline 8. Odor do sedimento (fundo) & Nenhum & Esgoto (ovo podre) & Óleo/industrial \\
\hline 9. Oleosidade do fundo & Ausente & Moderada & Abundante \\
\hline 10. Tipo de fundo & Pedra/cascalho & Lama/areia & Cimento/canalizado \\
\hline
\end{tabular}

Fonte - Callisto et al., 2002.

Além dos indicadores anteriores também foram incluídos parâmetros encontrados em outros trabalhos de referência, de forma a enriquecer a ferramenta com demais aspectos considerados relevantes para a avaliação. Do trabalho de Gomes et al. (2005), que avaliou impactos ambientais em nascentes, foram inseridos os parâmetros "presença de resíduos sólidos”; "materiais flutuantes"; "espumas"; "presença de animais"; "sinais de usos humanos"; e "proximidade de residências ou estabelecimentos". Do trabalho de Minatti - Ferreira e Beaumord (2006), cujo objetivo foi adequar um PAR para avaliar ecossistemas fluviais, foram utilizados os indicadores "estabilidade dos barrancos"; "proteção dos barrancos por vegetação"; e "grau de sombreamento das margens". Por 
fim, o último parâmetro adaptado (“alterações nos canais fluviais”) está no estudo de Rodrigues (2008), que elaborou um PAR para monitoramento de rios inseridos em campos rupestres.

\subsection{Seleção dos segmentos fluviais para aplicar o PAR}

O PAR elaborado foi aplicado na análise de 6 segmentos do Ribeirão da Prata. Para que diferentes condições do ambiente fluvial fossem devidamente representadas optou-se por selecionar trechos incluídos em diferentes contextos de uso e ocupação do solo. Assim, foram selecionados segmentos localizados tanto no interior quanto fora dos limites do parque (Figura 3).

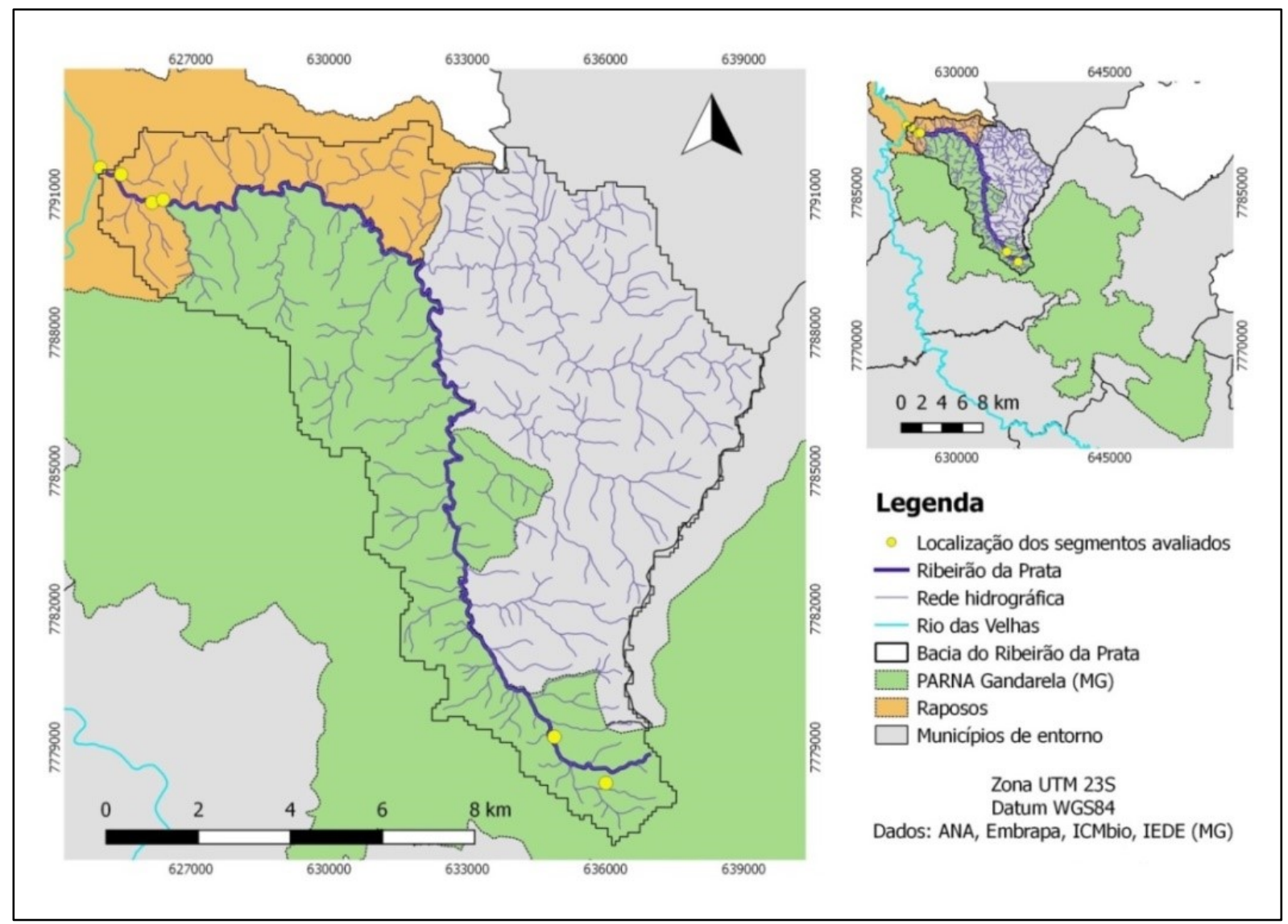

Figura 3 - Localização dos segmentos avaliados.

Não foi possível realizar avaliações em segmentos do médio curso, devido ao acesso restrito dentro dos limites do parque. Apesar disso, acredita-se que a avaliação realizada é representativa, já que no interior do PARNA não existem grandes variações no uso do solo (figura 4). 


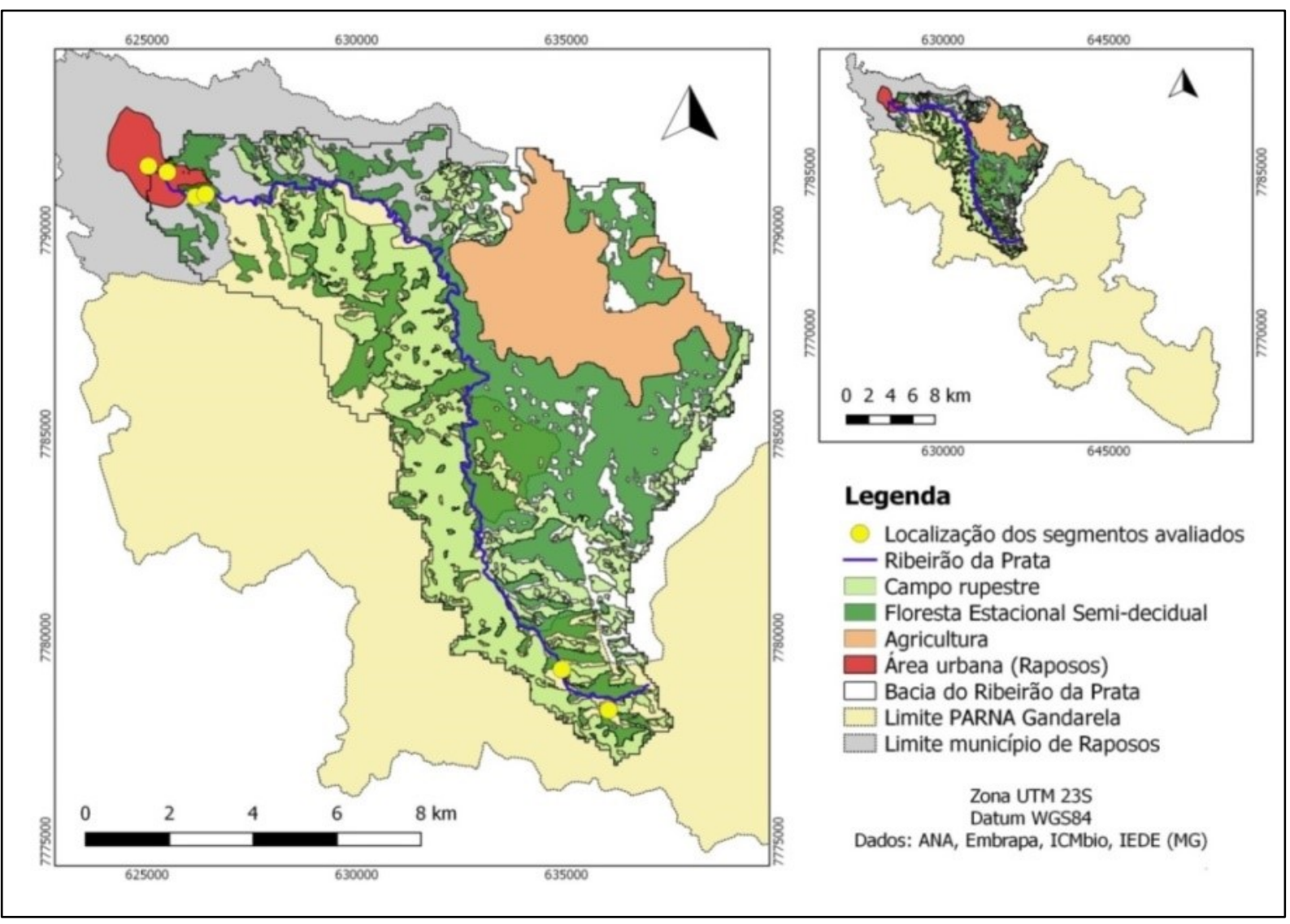

Figura 4 - Uso e ocupação do solo na bacia hidrográfica do Ribeirão da Prata.

No momento de aplicação da ferramenta buscou-se avaliar segmentos com 20 a 30 metros de extensão e relativamente homogêneos. Esta homogeneidade foi avaliada em campo através da identificação de trechos limitados por componentes naturais, como meandros e rupturas de declive.

\section{RESULTADOS}

\subsection{Protocolo de avaliação rápida e descrição de parametros}

A partir dos referenciais citados foi elaborada a proposta de Protocolo de Avaliação Rápida deste trabalho, que consiste no quadro de avaliação apresentado na Tabela 2. Como pode-se observar, os parâmetros são avaliados de acordo com três categorias, pontuadas de 0 a 4 . A pontuação final é obtida a partir do somatório dos valores atribuídos a cada parâmetro e refletem o nível de preservação ou degradação da qualidade ambiental dos trechos avaliados. A classificação final é dada de acordo com 3 intervalos de classes, que variam entre condições ambientais "ruins" (0 a 20), "intermediárias" (21 a 40) e "ótimas" (41 a 60). 
Tabela 2 - Protocolo de Avaliação Rápida elaborado.

\begin{tabular}{|c|c|c|c|c|}
\hline \multicolumn{5}{|l|}{ Localização: } \\
\hline Data da coleta: 1 & Hora da coleta: & & & \\
\hline \multicolumn{5}{|l|}{ Tempo (situação do dia): } \\
\hline \multirow{2}{*}{ Parâmetros } & \multicolumn{3}{|c|}{ Pontuação } & \multirow[b]{2}{*}{ Avaliação } \\
\hline & 4 pontos & 2 pontos & 0 pontos & \\
\hline $\begin{array}{l}\text { 1. Tipos de ocupação das } \\
\text { margens }\end{array}$ & Vegetação natural & $\begin{array}{c}\text { Campo de } \\
\text { pastagem/agricultura/monocultura/ } \\
\text { reflorestamento }\end{array}$ & $\begin{array}{c}\text { Residencial/comercial/ } \\
\text { industrial }\end{array}$ & \\
\hline $\begin{array}{l}\text { 2. Proximidade de } \\
\text { instalações residenciais, } \\
\text { comerciais ou industriais }\end{array}$ & Mais de 100 metros & Entre 50 em 100 metros & Menos de 50 metros & \\
\hline $\begin{array}{l}\text { 3. Obras e estruturas } \\
\text { hidráulicas }\end{array}$ & $\begin{array}{l}\text { Ausência. O curso d'água } \\
\text { segue com padrão natural }\end{array}$ & $\begin{array}{c}\text { Presença de área para apoio de } \\
\text { pontes; canalização pouco } \\
\text { extensiva }\end{array}$ & \begin{tabular}{|c|} 
Preseça de barragens \\
ou desvios; margens \\
revestidas por gabiões \\
ou cimento; extensa \\
canalização do curso \\
d'água \\
\end{tabular} & \\
\hline $\begin{array}{l}\text { 4. Fontes pontuais de } \\
\text { emissão de efluentes }\end{array}$ & Ausência. & $\begin{array}{c}\text { Emissão de esgoto/efluentes } \\
\text { domésticos }\end{array}$ & $\begin{array}{l}\text { Emissão de efluentes } \\
\text { químicos/industriais }\end{array}$ & \\
\hline $\begin{array}{l}\text { 5. Resíduos sólidos nas } \\
\text { margens }\end{array}$ & Ausência & Pouco & Muito & \\
\hline 6. Materiais flutuantes & Ausência & Pouco & Muito & \\
\hline 7. Espumas & Ausência & Pouca & Muita & \\
\hline 8. Odor da água & Nenhum & Esgoto & Químico/industrial & \\
\hline 9. Oleosidade da água & Ausente & Moderada & Abundante & \\
\hline 10. Transparência da água & Transparente & Turva/cor de chá forte & Opaca ou colorida & \\
\hline 11. Proteção das margens & $\begin{array}{c}70 \% \text { ou mais da superfície } \\
\text { coberta por vegetação natural, } \\
\text { afloramentos rochosos ou } \\
\text { outras estruturas naturais } \\
\text { estáveis }\end{array}$ & $\begin{array}{c}40 \text { a } 70 \% \text { da superfície coberta por } \\
\text { vegetação, afloramentos rochosos } \\
\text { e outras estruturas naturais } \\
\text { estáveis }\end{array}$ & $\begin{array}{c}\text { Menos de } 40 \% \text { das } \\
\text { superfície coberta por } \\
\text { vegetação, } \\
\text { afloramentos rochoros } \\
\text { e outras estruturas } \\
\text { naturais estáveis }\end{array}$ & \\
\hline $\begin{array}{l}\text { 12. Estabilidade das } \\
\text { margens à erosão e } \\
\text { movimentos de massa }\end{array}$ & $\begin{array}{l}\text { Poucas evidências de } \\
\text { cicatrizes de rupturas } \\
\text { (quedas) e focos de erosão } \\
\text { acelerada (sulcos, ravinas) }\end{array}$ & $\begin{array}{c}\text { Moderada perda de massa } \\
\text { sedimentar, com sinais recentes } \\
\text { de erosão e/ou quedas }\end{array}$ & $\begin{array}{c}\text { Evidências de } \\
\text { deslizamentos e } \\
\text { quedas recentes, com } \\
\text { barrancos instáveis }\end{array}$ & \\
\hline 13. Sombreamento & Vegetação com várias alturas & $\begin{array}{l}\text { Sombreamento completo da } \\
\text { superfície da água }\end{array}$ & $\begin{array}{c}\text { Superfície da água } \\
\text { totalmente exposta à } \\
\text { luz solar }\end{array}$ & \\
\hline $\begin{array}{l}\text { 14. Uso por animais } \\
\text { domésticos }\end{array}$ & Não detectado & Sinais pouco expressivos & Presença & \\
\hline 15. Usos humanos & Não detectado & Sinais pouco expressivos & Presença & \\
\hline
\end{tabular}




\subsubsection{Tipos de ocupação das margens}

Adaptado de Callisto et al., 2002, este indicador avalia o tipo de ocupação das margens e áreas próximas aos cursos d'água, considerando valores percentuais. A condição “ótima” envolve a presença de vegetação natural primária ou secundária em mais de $75 \%$ da área, sendo atribuída a nota 4. Em caso de ocupação por campos de pastagem, agricultura, monocultura e reflorestamento em 25\% ou mais da área, é atribuída condição “intermediária” (nota 2), já que apesar da possibilidade de impactos negativos (aceleração de processos erosivos e contaminação por agroquímicos, por exemplo) estes geralmente influenciam de maneira indireta os sistemas fluviais. Por fim, se a ocupação for residencial, comercial ou industrial em mais de $25 \%$ da área é dada nota 0 , devido a maiores chances de impactos diretos nos cursos d'água através do lançamento de materiais poluentes e aceleração de processos erosivos.

\subsubsection{Proximidade de instalações residenciais, comerciais ou industriais}

Este parâmetro, baseado em Gomes et al., (2005), parte do pressuposto de que quanto maior a proximidade com ocupações humanas, maiores as chances de ocorrência de impactos ambientais nos sistemas hídricos. Sendo assim, a avaliação se dá por meio de três categorias. A condição ideal é classificada como "ótima" (4 pontos) quando todas as instalações estiverem a uma distância maior que 100 metros. Como uma situação "intermediária” (2 pontos) estão os trechos onde instalações estão pelo menos entre 50 e 100 metros de distância. Por fim, a situação é "ruim" (0 pontos) quando a distância for de menos de 50 metros de construções humanas.

Com a finalidade de evitar um grau elevado de subjetividade, este parâmetro foi avaliado a partir da presença de 1 residência ou estabelecimento dentro das distâncias anteriormente referidas. Considerando que este protocolo é voltado para a avaliação de segmentos fluviais pouco extensos, entende-se que uma só residência/estabelecimento já oferece a possibilidade de exercer algum impacto significativo ao curso d'água, mesmo que este se dissipe ao longo da extensão fluvial.

\subsubsection{Obras e estruturas hidráulicas}

Qualquer ação que provoque uma mudança no curso natural dos fluxos pode acarretar em modificações e prejuízos na dinâmica do sistema fluvial. Estes tipos de mudanças, por sua vez, podem ser evidenciadas pela presença de estruturas construídas nos canais fluviais e áreas adjacentes, como pontes, canalizações, barramentos, entre outras. Neste parâmetro retirado de Rodrigues (2008) cursos d'água que não apresentam estruturas hidráulicas, seguindo seu padrão natural, são 
considerados em condição “ótima” (nota 4). Se há presença de alguma estrutura que interfira diretamente com suas margens, como bases para apoios de pontes, ou uma canalização pouco extensa, têm-se a situação considerada "intermediária" (nota 2). Por fim, quando há presença de diques, barragens, margens revestidas por gabiões ou cimento; e/ou extensa canalização do curso d'água, têm-se a situação "ruim" (nota 0 ).

A diferenciação entre as categorias "intermediária" e "ruim" define-se a partir dos tipos de estruturas associadas. Construções que interferem diretamente com as margens têm como principais impactos associados o aceleramento de processos erosivos e aumento da carga sedimentar escoada para o rio. Estruturas instaladas no interior canal, por sua vez, alteram diretamente os fluxos hídricos e sedimentológicos, influenciando toda a dinâmica do sistema fluvial.

\subsubsection{Fontes pontuais de emissão de efluentes}

Adaptado do parâmetro (3), “Alterações antrópicas”, de Callisto et al. (2002), este parâmetro avalia se há indícios de lançamento direto de efluentes no curso d'água. A condição ideal, caracterizada como ótima (4 pontos), corresponde à ausência de evidências de emissão de efluentes no corpo hídrico. Em uma situação intermediária (2) têm-se a evidência do lançamento de esgotos e outros efluentes domésticos. A situação "ruim" (0 pontos), por fim, corresponde à presença de evidências de emissão de efluentes químicos e/ou industriais.

\subsubsection{Resíduos sólidos nas margens}

A partir do parâmetro "Resíduos sólidos", baseado em Gomes et al., (2005), é avaliada a presença de resíduos sólidos nas margens dos trechos avaliados, cujos resultados variam entre a "ausência de resíduos sólidos" (4 pontos), "poucos resíduos sólidos” (2 pontos) e "muitos resíduos sólidos" (0 pontos).

\subsubsection{Materiais flutuantes}

O parâmetro "materiais flutuantes" de Gomes et al., 2005, denota a presença de materiais de origem antrópica que flutuam na água. Foram individualizadas três categorias: "ausência" (4 pontos), "baixa presença" ( 2 pontos) e "abundância" (0 pontos). 


\subsubsection{Espumas}

Este indicador refere-se a presença de espumas na superfície da água, que originam-se principalmente a partir do lançamento de efluentes industriais. A ausência de espumas é caracterizada como condição ideal, recebendo nota 4. A presença de pouca ou muita espuma são classificadas, respectivamente, com notas 2 e 0 (GOMES, et al. 2005).

\subsubsection{Odor da água}

Em suas condições naturais a água é inodora, sendo a presença de odores um indicador de alterações oriundas de impactos humanos ou processos naturais. Esta diferenciação deve ser realizada em campo, a partir da análise do aplicador. Este parâmetro é avaliado de acordo com três categorias: a ausência de odor é considerada como condição "ideal" (nota 4); o odor de esgoto é considerado como condição "intermediária" (nota 2); e o odor que remete a produtos químicos de origem industrial é classificado como "ruim" (nota 0) (CALLISTO, et al., 2002).

\subsubsection{Oleosidade da água}

A presença de oleosidade indica impactos de atividades humanas que utilizam e descartam óleos e graxas, como indústrias e postos de combustíveis, os quais podem ocasionar importantes consequências para o estado ambiental dos corpos hídricos. Sendo assim, a ausência de oleosidade é considerada como condição "ideal” (nota 4); a presença de pouca oleosidade enquadra-se em uma situação "intermediária" (nota 2); e a oleosidade abundante denota uma condição "ruim" (nota 0) (CALLISTO, et al., 2002).

\subsubsection{Transparência da água}

Em suas condições naturais a água deve ser transparente, o que denota condição "ideal” e nota 4. Águas turvas/com cor de chá forte podem sinalizar a presença de sedimentos, matéria orgânica e/ou substâncias poluentes no corpo receptor. Nos casos de impactos na turbidez por origem antrópica, as águas são categorizadas na condição "intermediária” e nota 2. A água opaca ou colorida, por sua vez, indica a presença de esgotos e/ou efluentes industriais, sendo categorizada como "ruim" (nota 0 ). Deve-se destacar que a transparência da água pode não ser um bom indicador de impactos antrópicos quando a sua redução ou ausência deve-se a fatores naturais derivados do substrato geológico ou de condições biológicas específicas (CALLISTO, et al., 2005). 


\subsubsection{Proteção das margens}

Este atributo retirado de Minatti-Ferreira e Beaumord (2006) avaliou a porcentagem de área das margens protegida por vegetação, afloramentos rochosos e outras estruturas naturais estáveis. As matas ciliares e de galeria são fatores dos mais importantes nesse sentido, contribuindo de diferentes maneiras para o equilíbrio das condições hidrogeomorfológicas dos sistemas fluviais. Em termos físicos, favorece a interceptação de parte da água de chuva e sua retenção no solo, influenciando a redução da velocidade dos fluxos superficiais e, consequentemente, a diminuição da suscetibilidade à erosão acelerada. As raízes também atuam nesse sentido, aumentando a permeabilidade e a capacidade de infiltração, fixando os solos e aumentando a sua resistência a processos erosivos. A existência de vegetação também permite a formação de uma cobertura morta (serrapilheira ou liteira) que exerce um papel protetor dos solos contra a exposição a agentes externos. Em termos físicoquímicos, a decomposição desta cobertura contribui também com o aumento de matéria orgânica nos solos, a qual exerce papel de elemento agregante das partículas.

Para avaliação deste atributo, considerou-se que as margens que apresentaram mais de $70 \%$ da superfície cobertas por vegetação, afloramentos ou outras estruturas naturais estáveis representam a condição ideal, ou seja, "ótima” (nota 4). O ambiente onde 40 a 70\% das superfícies das margens eram cobertas por vegetação, afloramentos rochosos e outras estruturas estruturas estáveis foi classificado como "regular" (nota 2). Margens com expressivas diferenças da condição ideal, onde foram observadas que menos de $40 \%$ das superfícies encontravam-se protegidas, foram classificadas na categoria "ruim" (nota 0$)$.

\subsubsection{Estabilidade das margens à erosão e a movimentos de massa}

Através deste parâmetro, também baseado em Minatti-Ferreira e Beaumord (2006), buscouse determinar se a área da margem estava erodida ou se havia potencial de erosão, considerando como condição ideal a presença de poucas cicatrizes de rupturas (quedas) e de erosão acelerada (sulcos), que foi caracterizada como "ótima" (nota 4). Margens com moderada perda de massa, onde foram observados sinais recentes de erosão e/ou de quedas, evidenciando a alteração de alguns aspectos de integridade do ambiente, foram caracterizadas como "razoáveis" (nota 2). A observação de quedas e/ou sulcos erosivos recentes, com barrancos instáveis que contribuem significativamente para o aumento da carga sedimentar dos canais, caracterizam o ambiente como "ruim" (nota 0 ). 


\subsubsection{Sombreamento}

O atributo "Sombreamento" foi baseado no parâmetro "Cobertura vegetal das margens", de Minatti-Ferreira e Beaumord (2006). Este indicador possui caráter ecológico e avalia o sombreamento fornecido à lâmina d'água, uma vez que a exposição completa ou ausência total de luz solar são fatores prejudiciais ao desenvolvimento das comunidades biológicas. Considera-se como condição ideal a alternância de sombras e luzes na superfície da água, para a manutenção de condições diversas para o desenvolvimento de ecossistemas. Tal condição pode ser observada em um ambiente onde há vegetação de vários portes (estratos), caracterizado como "ótimo" (nota 4). O sombreamento completo em um ecossistema caracteriza o ambiente como "razoável” (nota 2). A superfície da água totalmente exposta à luz solar, desfavorável para a instalação de comunidades, é considerada como condição oposta à ideal, sendo caracterizada como "ruim" (nota 0 ).

\subsubsection{Uso por animais domésticos}

Este indicador, adaptado de Gomes et al., (2005), considera as evidências do uso do segmento fluvial por animais, através de sinais como presença de fezes, esqueletos e pegadas. Considerando que estes aspectos podem gerar impactos negativos, principalmente relacionados à poluição dos corpos hídricos, a condição ideal é a ausência de sinais, considerada com a nota 4. Se existem apenas sinais pouco expressivos, a situação é classificada como "intermediária" (nota 2). Caso exista uma presença marcante, a situação é considerada "ruim", sendo atribuída nota 0. As evidências adotadas para a identificação de uso por animais domésticos foram identificadas em campo com base na observação.

\subsubsection{Usos humanos}

Por fim, o parâmetro "usos humanos" também de Gomes et al., (2005) indica evidências da utilização dos trechos fluviais que podem comprometer o estado ambiental do sistema, como trilhas, captações clandestinas, construção de barragens, lançamentos de efluentes, entre outros. A sua ausência é considerada situação "ideal", recebendo nota 4. Em caso de sinais pouco expressivos, atribui-se nota 2 (condição intermediária). Se há uma presença marcante, a situação é considerada como "ruim" (nota 0$)$. 


\section{APLICAÇÃO DO PROTOCOLO}

Foram selecionados 6 segmentos do Ribeirão da Prata para aplicação do protocolo desenvolvido, estando localizados tanto dentro dos limites do PARNA Gandarela (MG) quanto no município de Raposos (MG).

O Segmento 1 (Figura 5) corresponde a um trecho da zona de cabeceira do Ribeirão da Prata, inserido dentro dos limites do Parque. Este foi classificado com 60 pontos (nota máxima), sendo enquadrado, portanto, na categoria de condição ambiental "ótima”. A ocupação no entorno do sistema fluvial corresponde à vegetação natural ciliar. A mata se associa a um conjunto de afloramentos rochosos garantindo estabilidade às margens, que apresentam evidências pouco significativas de cicatrizes de ruptura e processos erosivos. A vegetação ciliar também exerce o papel de fornecer sombreamento adequado para a superfície da água, com a alternância entre áreas de sombra e áreas de incidência direta de radiação solar. Não foram identificados quaisquer sinais de interferência antrópica nas proximidades.
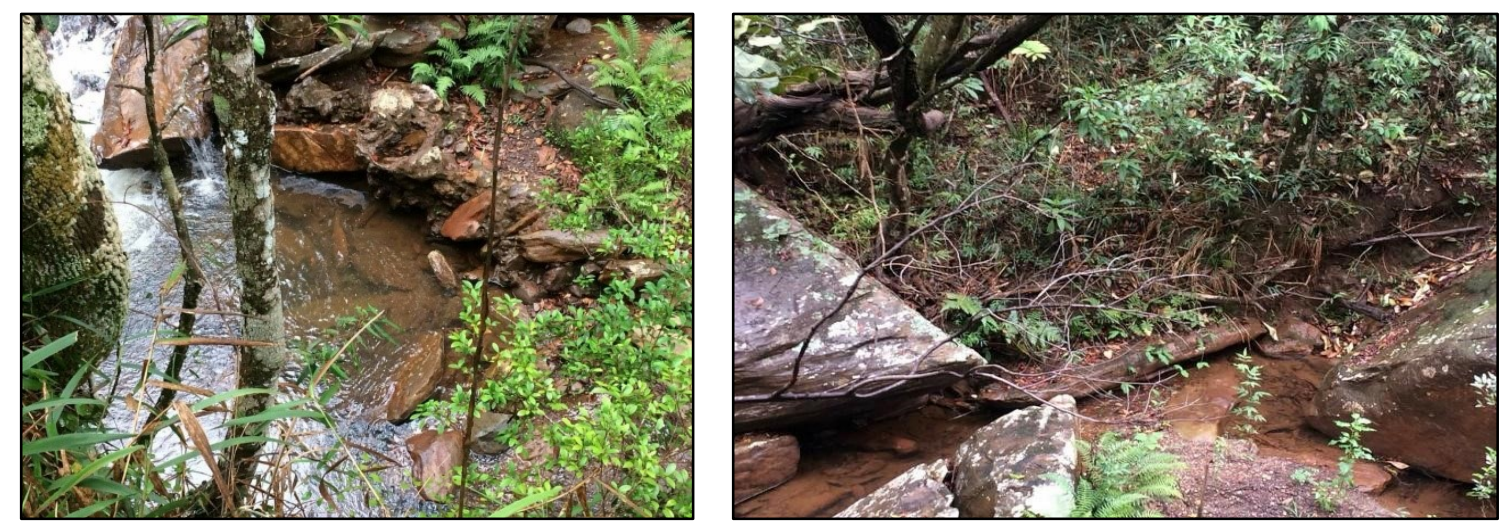

Figura 5 - Segmento 1.

O Segmento 2 (Figura 6) também se insere no alto curso da Bacia, dentro dos limites do Parque. Apesar de estar incluído em ambiente predominantemente natural, sua pontuação foi ligeiramente menor que a do segmento 1 . Classificado com 56 pontos, ainda enquadrado na categoria de qualidade ambiental "ótima", o trecho possui margens ocupadas por vegetação natural ciliar, que atua como agente estabilizador de processos erosivos. Não foram identificados quaisquer indícios de emissão de poluentes ou contaminantes na água. Além disso, há boas condições de sombreamento, proporcionadas pelos diferentes estratos da vegetação, que recobrem toda a área. A única alteração antrópica identificada é a existência de uma pequena ponte, que leva a pontuação "2" nos parâmetros "Alterações no canal" e "Usos humanos". 

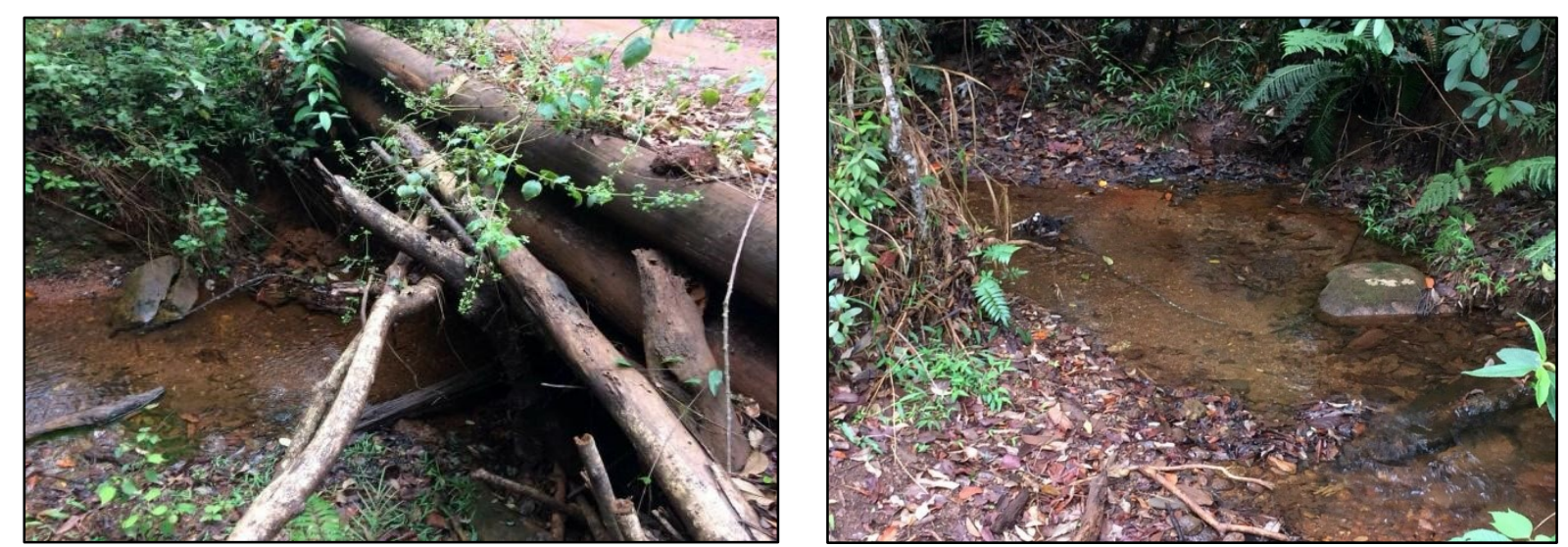

Figura 6 - Segmento 2.

O Segmento 3 (Figura 7) insere-se na porção média da bacia, no município de Raposos, fora dos limites do Parque. Classificado com a nota 48 (categoria "ótima"), têm as margens recobertas predominantemente por vegetação natural, não havendo ocupações humanas nas proximidades. As margens encontram-se protegidas, sendo poucas as evidências de solo exposto e processos erosivos. Os diferentes estratos da mata ciliar proporcionam sombreamento adequado da superfície da água. Apesar das boas condições aparentes de qualidade, a água foi caracterizada como opaca, indicando significativa carga sólida em suspensão.

No que se refere ao uso por animais domésticos, foi identificada a presença de fezes e pegadas, o que levou à classificação do parâmetro com a nota 0 . Com relação, por fim, ao uso por humanos, este foi identificado através da existência de trilhas logo ao lado do curso (nota 0 ).
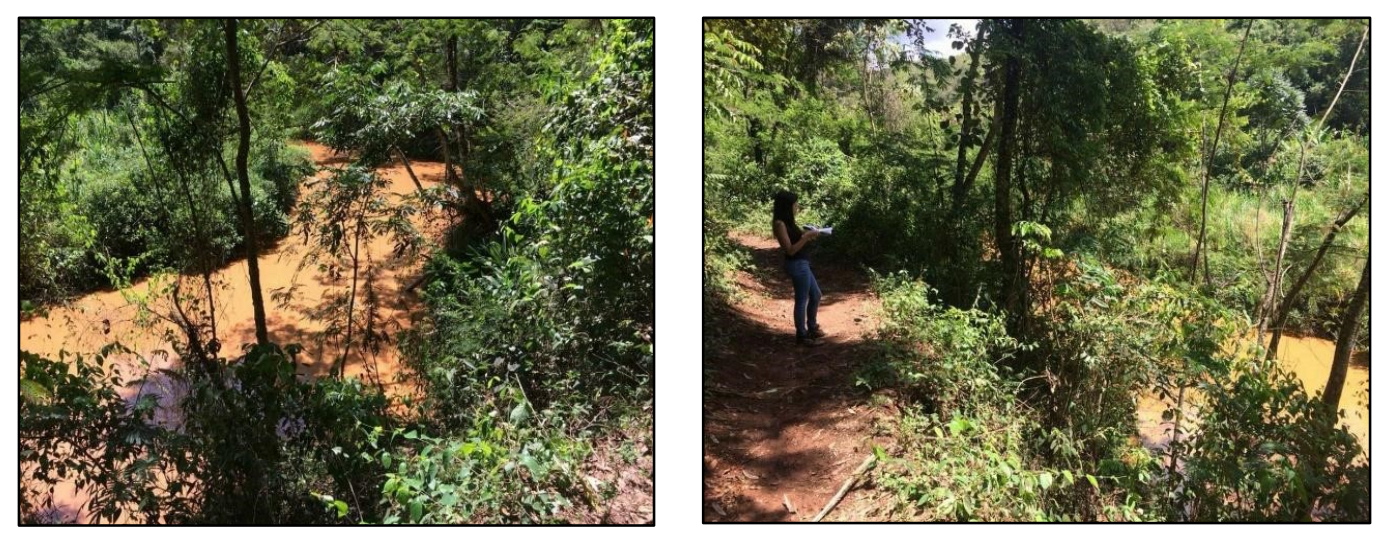

Figura 7 - Segmento 3.

O segmento 4 (Figura 8), delimitado a jusante do segmento 3, foi classificado com 34 pontos, que corresponde à categoria “intermediária”. A ocupação das margens é predominantemente natural, com poucas evidências de processos erosivos. Apesar da presença de mata ciliar, o sombreamento da superfície hídrica foi considerado insuficiente, uma vez que esta é demasiadamente aberta, permitindo a incidência direta de radiação solar. Não foram detectadas alterações de odor, oleosidade, espumas 
e materiais flutuantes na água, que, no entanto, se apresenta opaca. Ao longo das margens foram identificados resíduos sólidos em pequenas quantidades.

Foi detectada uma barragem de pequeno porte, que modifica a dinâmica do sistema fluvial. Com a instalação de uma barragem têm-se uma elevação do nível de base local, fator que influencia diretamente na alteração dos processos de transporte e deposição. À montante da estrutura passa a predominar processos deposicionais, que podem levar ao assoreamento do canal. À jusante pode ocorrer diminuição da lâmina d'água e aumento da capacidade erosiva devido à retenção da carga mais grosseira na barragem. Deste modo, foi atribuída nota 0 ao parâmetro "obras e estruturas hidráulicas".

O parâmetro "usos humanos" neste ponto também foi avaliado com nota 0 , como resultado da identificação de inúmeras evidências. Além da própria barragem, foi identificada a existência de dois casebres; de uma pequena instalação comercial nas proximidade; da trilha que deu acesso ao local; e de escritos nas estruturas de concreto. Além disso, no momento da avaliação havia a presença de um grupo de pessoas que utilizava o rio para recreação com contato primário. Também foi observada a existência de uma estrutura para contenção de animais, indicando a sua presença na área.

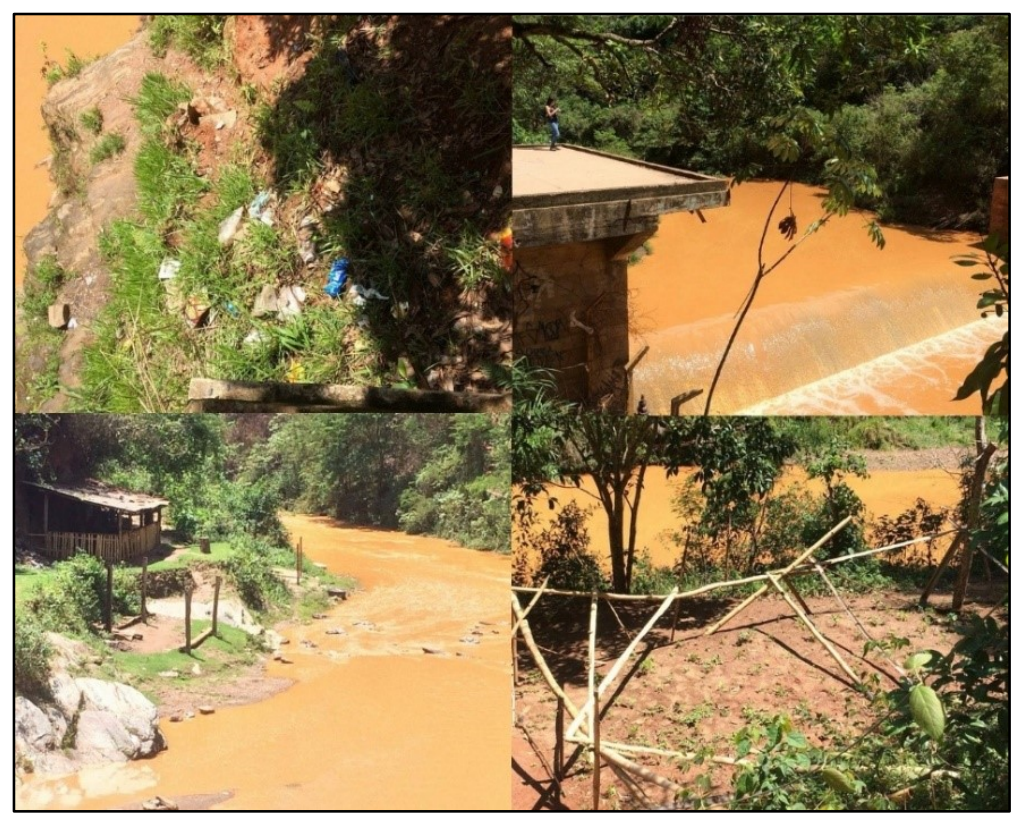

Figura 8 - Segmento 4.

O Segmento 5 (Figura 9) encontra-se inserido nas proximidades do centro de Raposos. Neste contexto, a ocupação é predominantemente residencial e comercial, com construções instaladas a menos de 50 metros do curso. Com relação às alterações no canal, foram identificadas áreas para apoio de pontes. As margens possuem menos de 40\% de área protegida por vegetação natural, sendo predominante a existência de vegetação rasteira e plantada. A maior parte do solo não encontra-se 
exposta, havendo poucos sinais de focos erosivos. O sombreamento da superfície da água é ineficiente, com total exposição à radiação solar.

Foi identificada grande quantidade de resíduos sólidos ao longo das margens. A água não apresenta materiais flutuantes, espumas e oleosidade, mas possui odor característico de esgoto, que é despejado diretamente no rio através de estruturas visíveis. Todos estes aspectos associados levaram à avaliação do segmento com a nota 24 , enquadrada na categoria "intermediária".

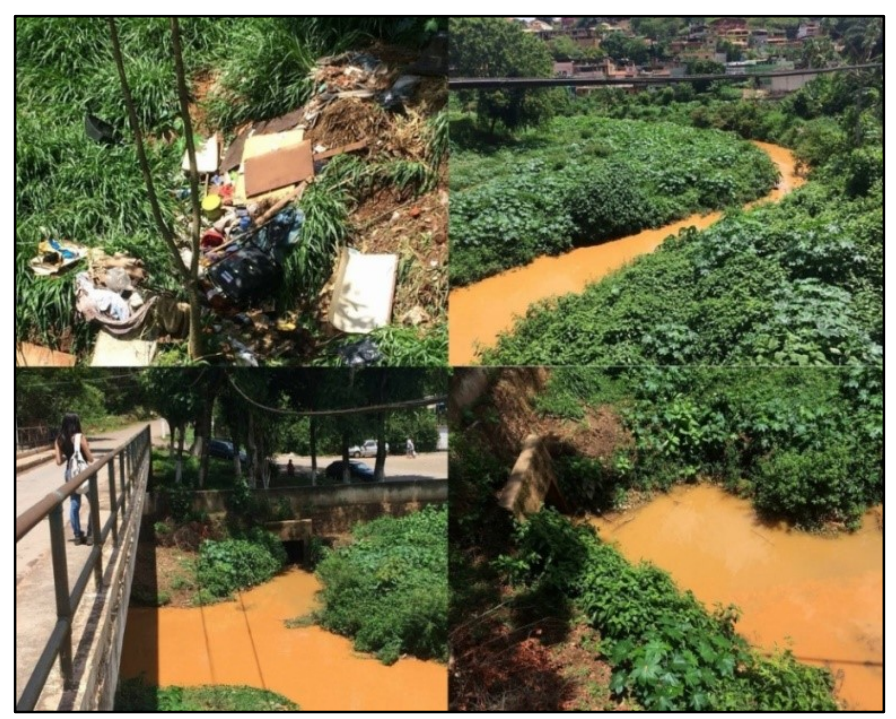

Figura 9 - Segmento 5.

O segmento 6 (Figura 10) corresponde à confluência do Ribeirão da Prata com o Rio das Velhas e foi classificado com nota 20 (categoria “ruim"). As margens e áreas próximas são ocupadas por construções residenciais e comerciais que, em muitos casos, despejam efluentes não tratados diretamente no curso d'água. Também ocorre grande quantidade de resíduos sólidos nas margens e materiais flutuantes na água. Esta apresenta forte odor de esgotos, grau elevado de opacidade e total exposição à incidência de radiação solar. Pôde-se observar que, apesar do alto nível de turbidez, a água possui tonalidade notavelmente diversa daquela observada no Rio das Velhas (mais escura). Foram detectadas evidências recentes de processos erosivos. Com relação a alterações no canal, foi identificada a presença de área para apoio de uma ponte, muito utilizada para o trânsito de pessoas e veículos. Não há trechos canalizados, com o curso d'água apresentando padrão morfológico natural. Na Tabela 3 é apresentada uma compilação das notas atribuídas a cada parâmetro, bem como a classificação final de todos os trechos. 


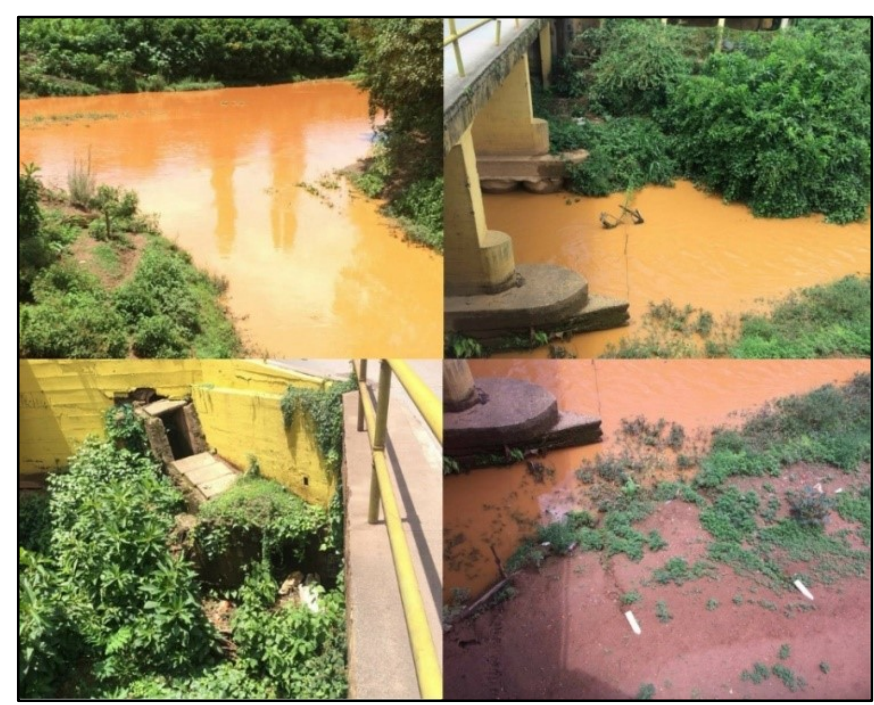

Figura 10 - Segmento 6.

Tabela 1 - Resultados da avaliação

\begin{tabular}{|c|c|c|c|c|c|c|}
\hline \multirow{2}{*}{ Parâmetros } & \multicolumn{6}{|c|}{ Segmentos } \\
\hline & 1 & 2 & 3 & 4 & 5 & 6 \\
\hline Tipos de ocupação das margens & 4 & 4 & 4 & 0 & 0 & 0 \\
\hline $\begin{array}{l}\text { Proximidade de instalações domésticas, } \\
\text { comerciais ou industriais }\end{array}$ & 4 & 4 & 4 & 4 & 0 & 0 \\
\hline Obras e estruturas hidráulicas & 4 & 2 & 4 & 0 & 2 & 2 \\
\hline Fontes pontuais de emissão de efluentes & 4 & 4 & 4 & 4 & 0 & 2 \\
\hline Resíduos sólidos & 4 & 4 & 4 & 2 & 0 & 0 \\
\hline Materiais flutuantes & 4 & 4 & 4 & 4 & 4 & 2 \\
\hline Espumas & 4 & 4 & 4 & 4 & 4 & 4 \\
\hline Odor da água & 4 & 4 & 4 & 4 & 2 & 2 \\
\hline Oleosidade da água & 4 & 4 & 4 & 4 & 4 & 4 \\
\hline Transparência da água & 4 & 4 & 0 & 0 & 0 & 0 \\
\hline Proteção das margens & 4 & 4 & 4 & 4 & 0 & 0 \\
\hline $\begin{array}{l}\text { Estabilidade das margens à erosão e } \\
\text { movimentos de massa }\end{array}$ & 4 & 4 & 4 & 4 & 4 & 2 \\
\hline Sombreamento & 4 & 4 & 4 & 0 & 0 & 0 \\
\hline Uso por animais domésticos & 4 & 4 & 0 & 0 & 4 & 2 \\
\hline Usos humanos & 4 & 2 & 0 & 0 & 0 & 0 \\
\hline Pontuação final & 60 & 56 & 48 & 34 & 24 & 20 \\
\hline
\end{tabular}




\section{DISCUSSÃO}

A partir da aplicação do PAR, foi possível verificar que dentro dos limites do PARNA Gandarela os segmentos fluviais apresentaram qualidade ambiental satisfatória, indicando que a unidade de conservação atende aos objetivos de proteção. No entanto, na medida em que se aproxima do município de Raposos notou-se um gradativo aumento nos níveis de intervenções antrópicas, que geram consequências negativas diretas nas condiçõs ambientais dos segmentos avaliados. O cenário analisado reflete o fato de que as ocupações humanas, principalmente de caráter urbano, ocasionam alterações consideráveis na dinâmica dos sistemas fluviais. Estas alterações, por sua vez, têm níveis variados, que podem ou não levar a um estado de baixa qualidade ambiental.

Com relação ao PAR elaborado, foi possível confirmar o grau significativo de subjetividade, havendo possibilidade de variação na avaliação dos parâmetros a depender da percepção do avaliador. Outro aspecto desfavorável relaciona-se com os valores utilizados para enquadrar os segmentos nas categorias de qualidade estabelecidas. As pontuações atribuídas, como qualquer outro modelo de compreensão da natureza, são formas de abstração da realidade, que por este motivo podem levar à desconsideração de certas particularidades importantes para a avaliação ambiental. Uma forma de reduzir esta distorção é aumentando-se o número de categorias avaliadas. Essa ação, no entanto, leva a um aumento da complexidade da ferramenta, que pode limitar a sua aplicação dependendo do objetivo e dos usuários. Diante deste contexto, acredita-se que o PAR deva ser utilizado como um instrumento de avaliação ambiental preliminar, cuja aplicação deverá ser sucedida por estudos mais aprofundados que gerem dados e conclusões consolidadas acerca das condições ambientais dos sistemas fluviais.

Apesar das limitações, o PAR permitiu a obtenção de resultados coerentes acerca das condições ambientais dos segmentos selecionados, cumprindo seu propósito como ferramenta de suporte ao diagnóstico ambiental. A viabilidade do instrumento é outro aspecto que favorece sua utilização: além de pouco oneroso em sua elaboração, sua aplicação é rápida, levando cerca de 15 a 20 minutos no caso do protocolo utilizado neste trabalho. Desta forma, acredita-se que a ferramenta possa ser utilizada para estudos posteriores e demais projetos de avaliação ambiental.

Diante destes aspectos, conclui-se que o PAR pode ter grande utilidade para a avaliação de sistemas fluviais, podendo ser aplicado por orgãos gestores e diferentes setores da sociedade, uma vez que não é necessária a atuação de especialistas. O instrumento pode ser utilizado, ainda, para promover ações de educação e conscientização ambiental. 


\section{CONSIDERAÇÕES FINAIS}

Os sistemas fluviais agregam elementos diversos, que interagem trocando fluxos de matéria e energia. Desta forma, torna-se cada vez mais limitada a realização de avaliações que abordem apenas o componente água, como é o caso da maioria das análises realizadas no Brasil. Neste sentido, acredita-se que os PARs, ao agregarem indicadores de categorias diversas, permitem a realização de uma avaliação que considera o curso d'água como um todo integrado, possibilitando um diagnóstico ambiental mais consistente. Além disso, estes instrumentos possuem alta viabilidade em sua utilização, tendo em vista os baixos custos para sua elaboração e a rapidez com que é aplicado.

A elaboração do PAR adaptado para avaliação da qualidade ambiental de sistemas fluviais e sua aplicação no estudo de caso do Ribeirão da Prata veio ilustrar a possibilidade de geração de ferramentas práticas e de fácil aplicação, além de pouco onerosas na análise ambiental. Os avanços e aprimoramentos da técnica, por sua vez, podem contribuir para a elaboração de outros instrumentos que se apoiem em uma abordagem integrada, dando subsídio a ações de gestão e planejamento. Por fim, cabe destacar que a facilidade de aplicação do PAR permite que qualquer segmento social possa empregá-lo, fato que vai de encontro às atuais diretrizes de incentivo à participação popular nas políticas de gestão de recursos hídricos.

\section{REFERÊNCIAS}

BARBOUR, M. T.; GERRITSEN, J.; SNYDER, B. D.; STRIBLING, J. B. Rapid Bioassessment Protocols for Use in Streams and Wadeable Rivers: Periphyton, Benthic Macroinvertebrates and Fish. 2. ed. Washington: EPA, 1999. 339p.

BIZZO, M. R. O.; MENEZES, J.; ANDRADE, S. F. Protocolos de avaliação rápida de rios (PAR). Caderno de estudos geoambientais, Rio de Janeiro, v. 4, n. 1, p. 5-13, 2014.

BRASIL. Decreto s/n, de 13 de outubro de 2014. Disponível em: < http://www.planalto.gov.br/ ccivil_03/_Ato2011-2014/2014/Dsn/Dsn14013.htm>. Acesso em: 26 de jan. 2019.

BRASIL. Resolução $\mathbf{n}^{\mathbf{0}}$ 357, de 17 de março de 2005. Disponível em: < http://www.mma.gov.br/port/conama/legiabre.cfm?codlegi=459>. Acesso em: 10 de jan. 2019.

BUSS, D. F.; BAPTISTA, D. F.; NESSIMIAN, J. L. Bases conceituais para a aplicação de biomonitoramento em programas de avaliação da qualidade da água de rios. Caderno Saúde Pública, Rio de Janeiro, v. 19, n. 2, p. 71-84, 2002.

CALLISTO, M.; FERREIRA, W. R.; MORENO, P.; GOULART, M.; PETRUCIO, M. Aplicação de um Protocolo de Avaliação Rápida da diversidade de habitats em atividades de ensino e pesquisa (MG - RJ). Acta Limnologica Brasiliensia, v. 14, n. 1, p. 91-98, 2002.

GOMES, P. M.; MELO, C.; VALE, V. S. Avaliação de impactos ambientais em nascentes na cidade de Uberlândia - MG: análise macroscópica. Sociedade e Natureza, Uberlândia, v. 17, n. 32, p. 103-120, 2005. 
HANNAFORD, M. J.; BARBOUR, M. T.; RESH, V. H. Training reduces observer variability in visualbased assessment of stream habitat. Journal of the North American Benthological Society. v. 16, n. 4, p. 853-860, 1997.

INSTITUTO CHICO MENDES DE CONSERVAÇÃO DA BIODIVERSIDADE (ICMbio). Proposta de Criação do Parque Nacional Serra do Gandarela. Setembro, 103p., 2010. Disponível em: $<$ http://www.icmbio.gov.br/portal/images/ stories/o-que-fazemos/PARQUE_GAN DARELA proposta_ICMBio.pdf $>$. Acesso em: 14 de jan. 2019.

LAMOUNIER, W. L.; CARVALHO, V. L. M.; SALGADO, A. A. R. Serra do Gandarela: possibilidade de ampliação das unidades de conservação no Quadrilátero Ferrífero. Revista do Departamento de Geografia - USP, São Paulo, v. 22, p. 171-192, 2011.

LEITE, A. C. C.; MAGALHÃES Jr, H.; LOPES, F.W.A. Avaliação da qualidade das águas para o uso recreacional na bacia do Ribeirão da Prata por meio do Índice de Condições de Balneabilidade - ICB. In: SIMPÓSIO BRASILEIRO DE RECURSOS HÍDRICOS. 21., 2015, Brasília. Anais... Brasília: Associação Brasileira de Recursos Hídricos, 2015, p. 1-8.

LEMOS, R. S.; CARVAlho, V. L. M.; MAGAlhães JR, A. P.; POLIGNANO, V. M.; LOPES, F. A. Elaboração de um protocolo de avaliação rápida de cursos d'água e aplicação em sub-bacias hidrográficas do ribeirão Pampulha, bacia do Rio das Velhas, Minas Gerais - Brasil. In: SEMINÁRIO NACIONAL SOBRE TRATAMENTO DE ÁREAS DE PRESERVAÇÃO PERMANENTE EM MEIO URBANO. 3., 2014, Presidente Prudente. Anais... Presidente Prudente, 2014. p. 1-13.

MINATTI-FERREIRA, D. D.; BEAUMORD, A. C. Adequação de um protocolo de avaliação rápida de integridade ambiental para ecossistemas de rios e riachos: aspectos físicos. Revista saúde e ambiente. Brusque, v. 7, n. 1, p. 39-47, 2006.

MONTEIRO, J. S. Indicadores de fragilidade à erosão no apoio à definição de áreas de preservação permanente em rios. 2014. 174f. Tese (Doutorado em Engenharia Florestal) - Centro de Ciências Rurais, Universidade Federal de Santa Maria, Santa Maria, 2014.

PLAFKIN, J. L.; BARBOUR, M. T.; PORTER, K. D.; HUGHES, R. M. Rapid bioassesment protocols for use in streams and rivers: benthic macroinvertebrates and fish. Washington: EPA, 1989. 339p.

RAPOSO, A. A.; BARROS, L. F. P.; MAGALHÃES JR, A. M. O uso de taxas de turbidez da bacia do alto Rio das Velhas - Quadrilátero Ferrífero/MG - como indicador de pressões humanas e erosão acelerada. Revista de Geografia. Recife, v. 27, n. 2, p. 34-50, 2010.

RODRIGUES, A. S. L. Adequação de um protocolo de avaliação rápida para o monitoramento e avaliação ambiental de cursos d'água inseridos em campos rupestres. 2008. 146f. Dissertação (Mestrado em geologia). Escola de Minas, Universidade Federal de Ouro Preto, Ouro Preto, 2008.

RODRIGUES, A. S. L; CASTRO, P. T. A. Protocolos de Avaliação Rápida: Instrumentos Complementares no Monitoramento dos Recursos Hídricos. Revista Brasileira de Recursos Hídricos. Ouro Preto, v. 13, n. 1, p. 161-170, 2008. 